\title{
Fungal rock phosphate solubilization using sugarcane bagasse
}

\author{
Gilberto O. Mendes $\cdot$ Carla S. Dias • \\ Ivo R. Silva · José Ivo Ribeiro Júnior • \\ Olinto L. Pereira $\cdot$ Maurício D. Costa
}

Received: 4 June 2012/ Accepted: 16 August 2012/Published online: 25 August 2012

(C) Springer Science+Business Media B.V. 2012

\begin{abstract}
The effects of different doses of rock phosphate (RP), sucrose, and $\left(\mathrm{NH}_{4}\right)_{2} \mathrm{SO}_{4}$ on the solubilization of $\mathrm{RP}$ from Araxá and Catalão (Brazil) by Aspergillus niger, Penicillium canescens, Eupenicillium ludwigii, and Penicillium islandicum were evaluated in a solid-state fermentation (SSF) system with sugarcane bagasse. The factors evaluated were combined following a $2^{3}+1$ factorial design to determine their optimum concentrations. The fitted response surfaces showed that higher doses of RP promoted higher phosphorus $(\mathrm{P})$ solubilization. The addition of sucrose did not have effects on $\mathrm{P}$ solubilization in
\end{abstract}

G. O. Mendes - C. S. Dias - M. D. Costa

Department of Microbiology, Universidade Federal de Viçosa, Av. PH Rolfs, s/n, Campus, Viçosa 36570-000, Brazil

e-mail: gilberto.mendes@ufv.br

C. S. Dias

e-mail: carla.dias@ufv.br

I. R. Silva

Department of Soil Science, Universidade Federal de Viçosa, Av. PH Rolfs, s/n, Campus, Viçosa 36570-000, Brazil e-mail: ivosilva@ufv.br

\section{J. I. R. Júnior}

Department of Statistics, Universidade Federal de Viçosa, Av. PH Rolfs, s/n, Campus, Viçosa 36570-000, Brazil e-mail: jivo@ufv.br

\section{O. L. Pereira}

Department of Plant Pathology, Universidade Federal de Viçosa, Av. PH Rolfs, s/n, Campus, Viçosa 36570-000, Brazil e-mail: oliparini@ufv.br

\section{D. Costa (ه)}

Bolsista CNPq-Brasil, Laboratório de Associações Micorrízicas, Instituto de Biotecnologia Aplicada à Agricultura (BIOAGRO), Av. P. H. Rolfs, s/n, Campus, Viçosa, MG 36570-000, Brazil e-mail: mdcosta@ufv.br most treatments due to the presence of soluble sugars in the bagasse. Except for A. niger, all the fungi required high $\left(\mathrm{NH}_{4}\right)_{2} \mathrm{SO}_{4}$ doses to achieve the highest level of $\mathrm{P}$ solubilization. Inversely, addition of $\left(\mathrm{NH}_{4}\right)_{2} \mathrm{SO}_{4}$ was inhibitory to $\mathrm{P}$ solubilization by A. niger. Among the fungi tested, A. niger stood out, showing the highest solubilization capacity and for not requiring sucrose or $\left(\mathrm{NH}_{4}\right)_{2} \mathrm{SO}_{4}$ supplementation. An additional experiment with A. niger showed that the content of soluble $\mathrm{P}$ can be increased by adding higher RP doses in the medium. However, P yield decreases with increasing RP doses. In this experiment, the maximal P yield (approximately $60 \%$ ) was achieved with the lower RP dose $\left(3 \mathrm{~g} \mathrm{~L}^{-1}\right)$. Our results show that SSF can be used to obtain a low cost biofertilizer rich in $\mathrm{P}$ combining RP, sugarcane bagasse, and A. niger. Moreover, sugarcane bagasse is a suitable substrate for SSF aiming at $\mathrm{RP}$ solubilization, since this residue can supply the $\mathrm{C}$ and $\mathrm{N}$ necessary for the metabolism of A. niger within a range that favors RP solubilization.

Keywords Waste - Fermentation biotechnology - Fungi · Biotechnology $\cdot$ Phosphorus

\section{Introduction}

Although phosphorus $(\mathrm{P})$ is abundant in many soils, it is one of the main limiting nutrients for plant growth because of its retention in soil particles, making it unavailable to plants. Frequent applications of soluble inorganic forms of $\mathrm{P}$ are therefore necessary to achieve satisfactory plant growth.

Soluble phosphate fertilizers are obtained from the chemical treatment of rock phosphate (RP) with acid at high temperatures. One of the drawbacks of this technology 
is the high cost involved in the process (Nahas et al. 1990). Moreover, it brings about unwanted environmental consequences due to the release of contaminants previously retained in the RP and the production of gases and byproducts resulting from the acid treatment (Vassilev and Vassileva 2003). The direct application of RPs may be an alternative to reduce the costs of phosphate fertilization and minimize pollution. However, due to the low reactivity of the majority of these rocks, their direct application is not, in many cases, adequate to satisfy the needs of plants on either a short- or long-term basis (Novais and Smith 1999).

The use of microorganisms capable of solubilizing RPs is a promising alternative for obtaining soluble $\mathrm{P}$ at a low cost and with reduced environmental damage. Several studies have been conducted to develop techniques for using microorganisms for large-scale phosphate solubilization (Nahas et al. 1990; Vassilev et al. 1996; Vassilev et al. 2001; Vassilev et al. 2006; Vassileva et al. 1998). Among these techniques, solid-state fermentation (SSF) has been shown to be efficient at providing appropriate conditions for the action of phosphate-solubilizing microorganisms. The use of SSF processes to produce soluble $\mathrm{P}$ from RP has been evaluated using agro-industrial residues such as olive cake (Vassilev et al. 2006; Vassileva et al. 1998) and sugar-beet (Vassilev et al. 1996; Vassilev et al. 2006). Seventy-six percent of the RP was solubilized by Aspergillus niger in an SSF system with sugar-beet residues as the substrate. In the same study, the fermentation product, rich in soluble $\mathrm{P}$, was used as a fertilizer in Trifolium repens plants and resulted in increased plant growth and P content (Vassilev et al. 1996).

Sugarcane bagasse is an abundant agro-industrial waste in Brazil and corresponds to, approximately, $30 \%$ of the sugarcane dry weight. It has desirable characteristics for SSF, such as high carbon and reduced ash contents compared to other crop residues (Soccol and Vandenberghe 2003). Sugarcane bagasse does not agglomerate after moistening with culture medium, allowing better heat and mass transfer during SSF (Kumar et al. 2003). Kumar et al. (2003) obtained $20.2 \mathrm{~g}$ citric acid in an SSF system with $100 \mathrm{~g}$ of sugarcane bagasse inoculated with A. niger. Sugarcane bagasse is, therefore, a promising alternative for SSF-based RP solubilization, given that the production of organic acid is the main mechanism of phosphate solubilization by microorganisms (Banik and Dey 1982; Reyes et al. 2001).

In some cases, the use of different agro-industrial residues in SSF systems requires the supplementation with carbon $(\mathrm{C})$ and nitrogen $(\mathrm{N})$ sources in addition to micronutrients. Depending on the $\mathrm{C}$ and $\mathrm{N}$ sources used, microorganisms will solubilize RPs at different efficiencies. Generally, $\mathrm{N}-\mathrm{NH}_{4}{ }^{+}$in the medium results in higher levels of phosphate solubilization than $\mathrm{N}^{-\mathrm{NO}_{3}}{ }^{-}$(Ahuja et al. 2007; Chuang et al. 2007). The effects of the C source on phosphate solubilization are variable and frequently depend on the microorganism being tested (Reyes et al. 1999; Ahuja et al. 2007). The optimal C and N concentrations in SSF systems for RP solubilization are not known. Different waste materials with distinct chemical compositions require appropriate $\mathrm{C}$ and $\mathrm{N}$ concentrations for achieving high levels of RP solubilization.

Another factor that influences microbial phosphate solubilization is the $\mathrm{P}$ source concentration. For Yichang RP ( $8.35 \%$ P), Xiao et al. (2008) showed that the RP concentration that provided the highest level of solubilization in liquid culture medium was $2.5 \mathrm{~g} \mathrm{~L}^{-1}$. However, due to the high variability in RP composition and reactivity, specific studies are necessary to define the appropriate concentration for each RP.

Thus, the aims of this study were to evaluate the solubilization of Araxá and Catalão RPs by fungal isolates in an SSF system using sugarcane bagasse as the substrate, and to study the effects of different doses of RP, sucrose, and $\left(\mathrm{NH}_{4}\right)_{2} \mathrm{SO}_{4}$ on the solubilization process.

\section{Materials and methods}

\section{Microorganisms}

The isolates A. niger FS1, Penicillium canescens FS23, Eupenicillium ludwigii FS27, and Penicillium islandicum FS30 used in this study were maintained at $28{ }^{\circ} \mathrm{C}$ on Petri dishes containing potato-dextrose-agar (PDA). The isolates belong to the Collection of Phosphate Solubilizing Fungi, Institute of Biotechnology Applied to Agriculture (BIOAGRO), Federal University of Viçosa, Viçosa, MG, Brazil.

\section{Culture media and fermentation conditions}

$\mathrm{N}, \mathrm{P}$, and soluble sugar contents of the sugarcane bagasse used as substrate for the SSF system, in $\mathrm{g} \mathrm{kg}^{-1}$, were 3.4, 0.6 , and 300 , respectively. The bagasse was ground into fragments of up to $2 \mathrm{~mm}$ in length and added at a ratio of $10 \%(\mathrm{w} / \mathrm{v})$ to $125-\mathrm{mL}$ Erlenmeyer flasks containing $50 \mathrm{~mL}$ of modified Czapek's solution $\left(0.5 \mathrm{~g} \mathrm{~L}^{-1} \mathrm{MgSO}_{4}\right.$. $7 \mathrm{H}_{2} \mathrm{O}, 0.5 \mathrm{~g} \mathrm{~L}^{-1} \mathrm{KCl}, 0.01 \mathrm{~g} \mathrm{~L}^{-1} \mathrm{FeSO}_{4}$ ). Araxá (32\% $\mathrm{P}_{2} \mathrm{O}_{5}$ ) and Catalão (34\% $\left.\mathrm{P}_{2} \mathrm{O}_{5}\right)$ RPs were added separately to the fermentation medium at concentrations of $0.5,1.75$, and $3 \mathrm{~g} \mathrm{~L}^{-1}$. $\left(\mathrm{NH}_{4}\right)_{2} \mathrm{SO}_{4}$ at 0,1 , and $2 \mathrm{~g} \mathrm{~L}^{-1}$ and sucrose at 0,5 , and $10 \mathrm{~g} \mathrm{~L}^{-1}$ were also tested. These different doses of RPs, sucrose, and $\left(\mathrm{NH}_{4}\right)_{2} \mathrm{SO}_{4}$ were combined following the experimental design displayed in Table 1. After sterilization at $121{ }^{\circ} \mathrm{C}$ for $30 \mathrm{~min}$, the flasks were inoculated with five 7-mm-diameter disks containing fungal mycelium taken from the edges of five-day-old colonies and 
Table 1 Solubilized P from Araxá or Catalão rock phosphates (RP) by fungal isolates under different combinations of $\mathrm{RP},\left(\mathrm{NH}_{4}\right)_{2} \mathrm{SO}_{4}$, and sucrose doses

\begin{tabular}{|c|c|c|c|c|c|c|c|c|c|c|c|}
\hline \multirow[t]{3}{*}{ Treatment } & \multirow{3}{*}{$\begin{array}{l}\mathrm{RP} \\
\left(\mathrm{g} \mathrm{L}^{-1}\right)\end{array}$} & \multirow{3}{*}{$\begin{array}{l}\left(\mathrm{NH}_{4}\right)_{2} \mathrm{SO}_{4} \\
\left(\mathrm{~g} \mathrm{~L}^{-1}\right)\end{array}$} & \multirow{3}{*}{$\begin{array}{l}\text { Sucrose } \\
\left(\mathrm{g} \mathrm{L}^{-1}\right)\end{array}$} & \multicolumn{8}{|c|}{ Solubilized $\mathrm{P}^{\mathrm{b}}\left(\mathrm{mg} \mathrm{L}^{-1}\right)$} \\
\hline & & & & \multicolumn{4}{|c|}{ Araxá RP } & \multicolumn{4}{|c|}{ Catalão RP } \\
\hline & & & & A. niger & P. canescens & E. ludwigii & P. islandicum & A. niger & P. canescens & E. ludwigii & P. islandicum \\
\hline 1 & 0.5 & 0 & 0 & 49.0 & 7.5 & -19.1 & -19.8 & 43.9 & 2.8 & -10.6 & -9.9 \\
\hline 2 & 3 & 0 & 0 & 239.3 & 13.0 & -8.8 & -8.7 & 259.6 & 14.9 & -6.4 & -4.3 \\
\hline 3 & 0.5 & 2 & 0 & 50.3 & -12.0 & -7.2 & -14.5 & 56.1 & -0.9 & 6.5 & -4.2 \\
\hline 4 & 3 & 2 & 0 & 114.0 & 26.0 & 11.6 & -3.7 & 130.6 & 24.3 & 19.0 & 6.2 \\
\hline 5 & 0.5 & 0 & 10 & 34.9 & 1.4 & -19.6 & -15.6 & 50.8 & -4.5 & -9.9 & -8.5 \\
\hline 6 & 3 & 0 & 10 & 148.8 & 9.1 & -0.3 & -17.0 & 197.8 & 22.5 & -0.7 & 0.3 \\
\hline 7 & 0.5 & 2 & 10 & 30.7 & -10.3 & -8.7 & -17.2 & 47.8 & 0.0 & 3.7 & -6.1 \\
\hline 8 & 3 & 2 & 10 & 108.4 & 27.5 & 14.2 & 12.4 & 139.8 & 5.3 & 21.4 & 11.1 \\
\hline $9^{a}$ & 1.75 & 1 & 5 & 75.6 & 8.5 & -1.5 & -5.6 & 78.1 & 8.2 & 13.2 & -1.2 \\
\hline
\end{tabular}

The first four columns show the combinations of the factors in each treatment in the experimental design

${ }^{a}$ Central point

b Solubilized $\mathrm{P}$ was calculated by the difference between soluble $\mathrm{P}$ in the inoculated samples and in the uninoculated flasks (Soluble $\mathrm{P}$ in uninoculated flasks ( $\mathrm{mg} \mathrm{L}^{-1}$ ): Araxá RP, 24.6; Catalão RP, 14.8. Part of this $\mathrm{P}\left(13.3 \mathrm{mg} \mathrm{L}^{-1}\right.$ ) is derived from the sugarcane bagasse.)

incubated at $30{ }^{\circ} \mathrm{C}$ for 10 days. Uninoculated flasks were also incubated to determine the soluble $\mathrm{P}$ in the bagasse and the $\mathrm{P}$ solubilized by abiotic processes.

\section{Analytical methods}

After the incubation, the aqueous phase of the fermentation medium was extracted by manual compression of the bagasse into a funnel covered with quantitative filter paper. The resulting filtrate was used to determine $\mathrm{P}$ concentrations by the ascorbic acid method in a spectrophotometer at wavelength of $725 \mathrm{~nm}$ (Braga and Defelipo 1974). Solubilized P was calculated by the difference between soluble $P$ in the inoculated samples and in the uninoculated flasks. P yield was expressed as the percentage of solubilized $\mathrm{P}$ obtained in relation to the total $\mathrm{P}$ content in the RPs. The $\mathrm{pH}$ of the filtrate was measured and the titratable acidity determined by titrating $5 \mathrm{~mL}$ of the filtrate up to $\mathrm{pH} 7.0$ with $0.1 \mathrm{M} \mathrm{NaOH}$ using bromothymol blue as indicator.

\section{Experimental design and statistical analyses}

To determine the optimum combination of the three factors evaluated ( $\mathrm{RP},\left(\mathrm{NH}_{4}\right)_{2} \mathrm{SO}_{4}$, and sucrose doses), a $2^{3}+1$ factorial design with three replications at the central point was used. The experimental design with the combinations of the factors evaluated is shown in Table 1. Altogether, eight experiments were conducted, corresponding to the combinations of the four fungal isolates with the two RPs evaluated (Table 1).
The response surfaces were fitted through the least squares method using the statistical software Minitab 15. Variance analysis with a lack of fit test for the response surface was performed, and the coefficients were tested using a $t$ test up to $10 \%$ probability. The largest response surface model adopted was:

$$
\begin{aligned}
y_{i j k l}= & \beta_{0}+\beta_{1} R_{i}+\beta_{2} A_{j}+\beta_{3} S_{k}+\beta_{4} R_{i} A_{i} S_{j} \\
& +\beta_{5} R_{i} S_{i} C_{k}+\beta_{6} A_{j} S_{k}+e_{i j k l}
\end{aligned}
$$

where:

$\mathrm{y}_{\mathrm{ijkl}} \quad$ Value of solubilized $\mathrm{P}$ observed with the combination of $\mathrm{RP}_{\mathrm{i}}, \mathrm{AS}_{\mathrm{j}}$ and $\mathrm{SC}_{\mathrm{k}}$ used in replication 1

$\beta_{0} \quad$ Regression constant

$\beta_{1} \quad$ Regression coefficient of the linear effect of RP (rock phosphate)

$\beta_{2} \quad$ Regression coefficient of the linear effect of AS (ammonium sulfate)

$\beta_{3} \quad$ Regression coefficient of the linear effect of SC (sucrose)

$\beta_{4} \quad$ Regression coefficient of the effect of the interaction between RP and AS

$\beta_{5} \quad$ Regression coefficient of the effect of the interaction between RP and SC

$\beta_{6} \quad$ Regression coefficient of the effect of the interaction between AS and SC

$\mathrm{e}_{\mathrm{ijkl}}$ Effect of the experimental error associated with the observation $\mathrm{y}_{\mathrm{ijk}}$

To determine the fitted response surface with the presence of only significant coefficients, those coefficients that 
were not significant by the $t$ test $(p<0.10)$ were removed one at a time, starting with the interactions. The coefficient of determination $\left(\mathrm{R}^{2}\right)$ was also considered for verifying the adjustment of the model. To visualize the data, surface response plots were built.

For the isolate A. niger FS1, an additional experiment was conducted using the same SSF conditions defined previously while varying the doses of the two RPs $(3.0,4.5$, 6.0, 7.5, and $9.0 \mathrm{~g} \mathrm{~L}^{-1}$ ). In this experiment, neither $\left(\mathrm{NH}_{4}\right)_{2} \mathrm{SO}_{4}$ nor sucrose was added. This experiment was conducted using an entirely randomized design with three replications at the central point $\left(6.0 \mathrm{~g} \mathrm{~L}^{-1}\right)$ followed by regression analysis. The Pearson correlation coefficients between the variables studied were also analyzed. The experimental design and the statistical analyses were done using the statistical software Minitab 15.

\section{Results}

Effects of different sucrose, $\left(\mathrm{NH}_{4}\right)_{2} \mathrm{SO}_{4}$ and RP doses

The fungal isolates showed distinct solubilization potentials and, depending on the medium supplementation treatments, distinct behaviors were observed for a single isolate when grown in the presence of different RPs (Table 1, 2). Negative values of solubilized $P$ were observed for the treatments (Table 1) in which the fungus immobilized $\mathrm{P}$ derived from sugarcane bagasse and abiotic RP solubilization, being not able to solubilize significant $\mathrm{P}$ amounts from the RPs. For all the combinations of isolates and RPs, the highest dose of RP added to the SSF system $\left(3.0 \mathrm{~g} \mathrm{~L}^{-1}\right)$ promoted higher levels of solubilized $\mathrm{P}$ (Table 1). $\left(\mathrm{NH}_{4}\right)_{2} \mathrm{SO}_{4}$ supplementation influenced $\mathrm{RP}$ solubilization for most of the treatments evaluated in this study (Table 2), however, the response to this compound varied depending on the fungal isolate and RP combination tested. Sucrose improved the level of solubilized P only when $P$. islandicum FS30 was combined with Catalão RP (Table 2).

Aspergillus niger FS1 promoted the highest levels of solubilized P for both RPs (Table 1). A positive effect of increasing RP doses on the levels of solubilized $\mathrm{P}$ was observed for both RPs in the treatments with A. niger FS1 (Table 2; Figs. 1a, 2a). The regression equations for A. niger $\mathrm{FS} 1$ shows that, although $\left(\mathrm{NH}_{4}\right)_{2} \mathrm{SO}_{4}$ addition was not significant by itself, the nitrogen source doses in the medium correlated negatively with RP doses. Since the RP coefficient is positive, the negative coefficient corresponding to the interaction between $\mathrm{RP}$ and $\left(\mathrm{NH}_{4}\right)_{2} \mathrm{SO}_{4}$ in the equations indicates that higher $\mathrm{P}$ solubilization is achieved combining high RP doses with low $\left(\mathrm{NH}_{4}\right)_{2} \mathrm{SO}_{4}$ (Table 2). This effect is clearly shown in the surface response graphs (Figs. 1a, 2a). Moreover, a negative correlation between $\left(\mathrm{NH}_{4}\right)_{2} \mathrm{SO}_{4}$ concentration and titratable acidity was observed for both Araxá and Catalão RPs ( $-0.76, p<0.01$, and $-0.70, p<0.05$, respectively).

$\left(\mathrm{NH}_{4}\right)_{2} \mathrm{SO}_{4}$ addition promoted different patterns of solubilized $\mathrm{P}$ in the treatments with $P$. canescens FS23 and Araxá RP (Fig. 1b). At lower RP doses, as $\left(\mathrm{NH}_{4}\right)_{2} \mathrm{SO}_{4}$ concentrations increased, phosphate solubilization was reduced. Inversely, at higher RP doses, a positive effect of increasing $\left(\mathrm{NH}_{4}\right)_{2} \mathrm{SO}_{4}$ concentrations was recorded (Fig. 1b), achieving a maximum yield of solubilized $\mathrm{P}$ of $7 \%$ for Araxá RP (Table 1). In the medium supplemented with Catalão RP, only the RP doses influenced P solubilization by $P$. canescens FS23 (Table 2). Higher yields of solubilized $\mathrm{P}$ were obtained with increasing RP doses in the

Table 2 Regression equation for the levels of solubilized P by the fungal isolates as a function of Araxá or Catalão rock phosphate (RP), $\left(\mathrm{NH}_{4}\right)_{2} \mathrm{SO}_{4}(\mathrm{AS})$ and sucrose (SC) doses

\begin{tabular}{|c|c|c|c|}
\hline Isolate & Regression equation & $\mathrm{R}^{2}$ & Figure \\
\hline \multicolumn{4}{|l|}{ Araxá RP } \\
\hline A. niger FS1 & $\hat{\mathrm{Y}}=5.7+60.8^{* *} \mathrm{RP}+7.4 \mathrm{AS}-16.3^{\dagger} \mathrm{RP} \mathrm{AS}$ & 0.85 & $1 \mathrm{a}$ \\
\hline P. canescens $\mathrm{FS} 23$ & $\hat{\mathrm{Y}}=3.3+2.6 \mathrm{RP}-10.9 * * \mathrm{AS}+6.3^{* *} \mathrm{RP} \mathrm{AS}$ & 0.94 & $1 b$ \\
\hline E. ludwigii FS27 & $\hat{\mathrm{Y}}=-23.5+7.1 * * \mathrm{RP}+7.2^{* *} \mathrm{AS}$ & 0.91 & $1 \mathrm{c}$ \\
\hline P. islandicum $\mathrm{FS} 30$ & $\hat{\mathrm{Y}}=-17.3+1.9 \mathrm{RP}-0.6 \mathrm{AS}+3.1^{\dagger} \mathrm{RP} \mathrm{AS}$ & 0.68 & $1 d$ \\
\hline \multicolumn{4}{|l|}{ Catalão RP } \\
\hline A. niger FS1 & $\hat{\mathrm{Y}}=0.8+72.5^{* *} \mathrm{RP}+12.1 \mathrm{AS}-19.6^{*} \mathrm{RP}$ AS & 0.89 & $2 \mathrm{a}$ \\
\hline P. canescens $\mathrm{FS} 23$ & $\hat{\mathrm{Y}}=-4.1+6.9^{* *} \mathrm{RP}$ & 0.70 & - \\
\hline E. ludwigii FS27 & $\hat{\mathrm{Y}}=-11.7+4.4 * \mathrm{RP}+9.7 * * \mathrm{AS}$ & 0.77 & $2 b$ \\
\hline P. islandicum $\mathrm{FS} 30$ & $\hat{\mathrm{Y}}=-9.8+1.9^{*} \mathrm{RP}+1.4 \mathrm{AS}-0.1 \mathrm{SC}+1.3^{*} \mathrm{RP} \mathrm{AS}+0.2^{\dagger} \mathrm{RP} \mathrm{SC}$ & 0.97 & 3 \\
\hline
\end{tabular}

** Significant by the $t$ test $(p<0.01)$

* Significant by the $t$ test $(p<0.05)$

$\dagger$ Significant by the $t$ test $(p<0.10)$ 

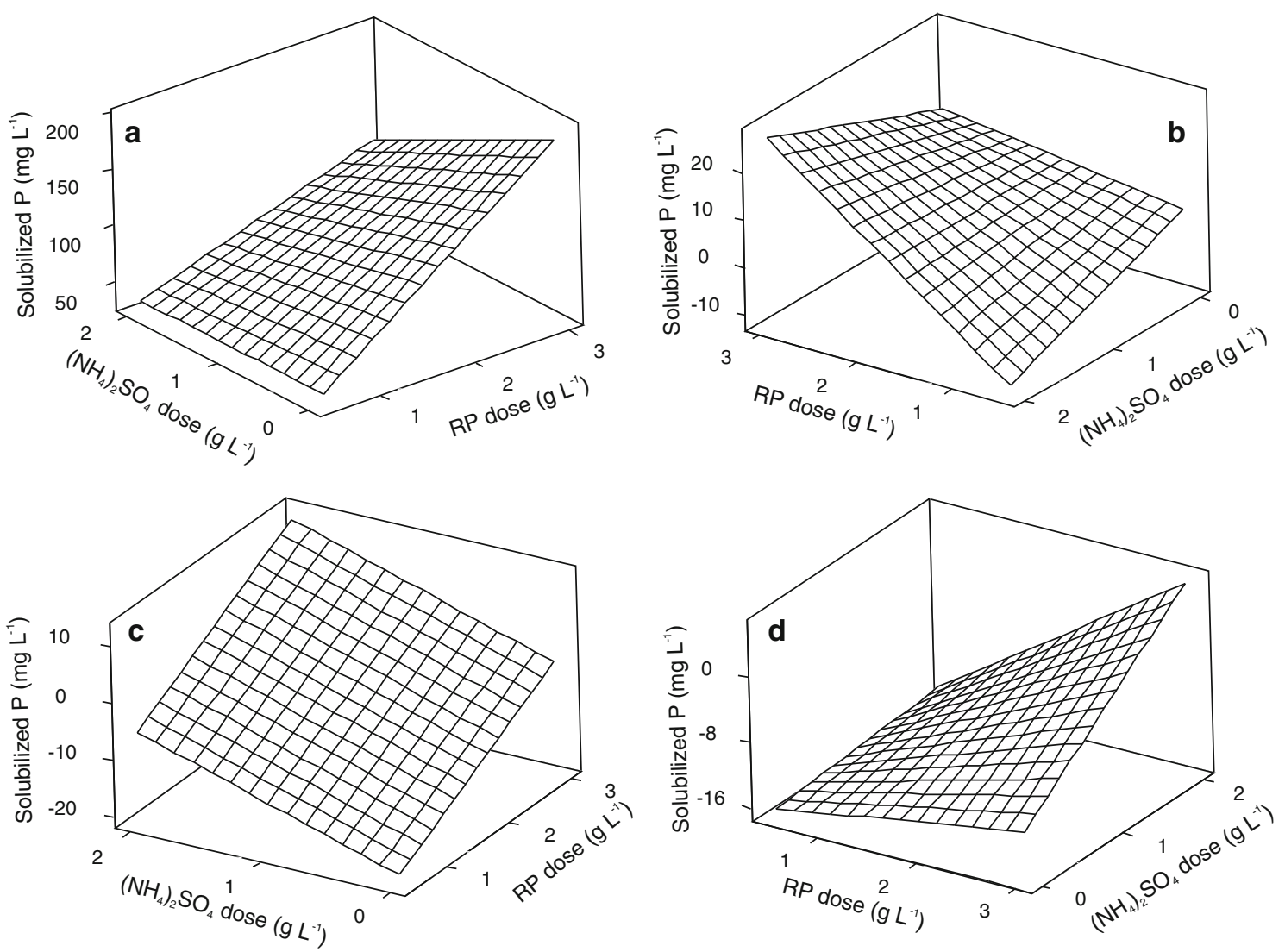

Fig. 1 Estimates of the level of solubilized $\mathrm{P}$ as a function of the Araxá rock phosphate $(\mathrm{RP})$ and $\left(\mathrm{NH}_{4}\right)_{2} \mathrm{SO}_{4}$ doses achieved by the isolates a A. niger FS1, b $P$. canescens FS23, c E. ludwigii FS27 and d P. islandicum FS30
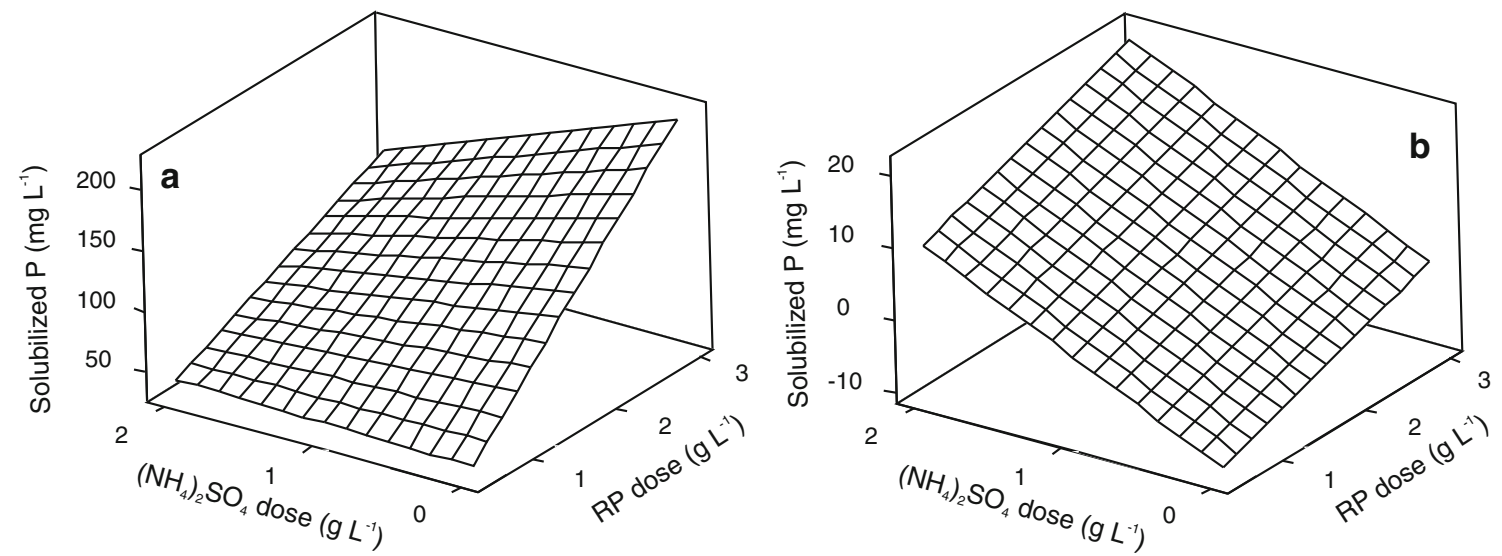

Fig. 2 Estimates of the level of solubilized $\mathrm{P}$ as a function of the Catalão rock phosphate (RP) and $\left(\mathrm{NH}_{4}\right)_{2} \mathrm{SO}_{4}$ doses achieved by the isolates a A. niger FS1 and b E. ludwigii FS27

growth medium (Table 1), however, the highest $\mathrm{P}$ yield corresponded to only $5 \%$ of the P present in Catalão RP.

Eupenicillium ludwigii FS27 showed similar patterns of solubilization for the two RPs evaluated. Increasing RP and $\left(\mathrm{NH}_{4}\right)_{2} \mathrm{SO}_{4}$ doses led to higher $\mathrm{P}$ solubilization, with no interactions between RPs and N source (Table 2; Figs. 1c, 2b). The highest $\mathrm{P}$ yield obtained corresponded to 3 and $5 \%$ of the $\mathrm{P}$ present in Araxá and Catalão RPs, respectively.

In the medium with Araxá RP, inoculated with $P$. islandicum FS30, a positive interaction between RP doses and increasing $\left(\mathrm{NH}_{4}\right)_{2} \mathrm{SO}_{4}$ concentrations was 
observed (Table 2; Fig. 1d). The highest $\mathrm{P}$ yield achieved by $P$. islandicum FS30 corresponded to, approximately, $3 \%$ of the total $\mathrm{P}$ in the Araxá RP. When P. islandicum FS30 was grown in media with Catalão RP, effects of the $\mathrm{RP}$ doses and of the interaction between RP and $\left(\mathrm{NH}_{4}\right)_{2} \mathrm{SO}_{4}$ and of $\mathrm{RP}$ and sucrose could be observed (Table 2). All the interactions were positive, showing that the combination of higher Araxá $\mathrm{RP},\left(\mathrm{NH}_{4}\right)_{2} \mathrm{SO}_{4}$, and sucrose doses allowed for increased levels of solubilized $\mathrm{P}$ (Fig. 3).
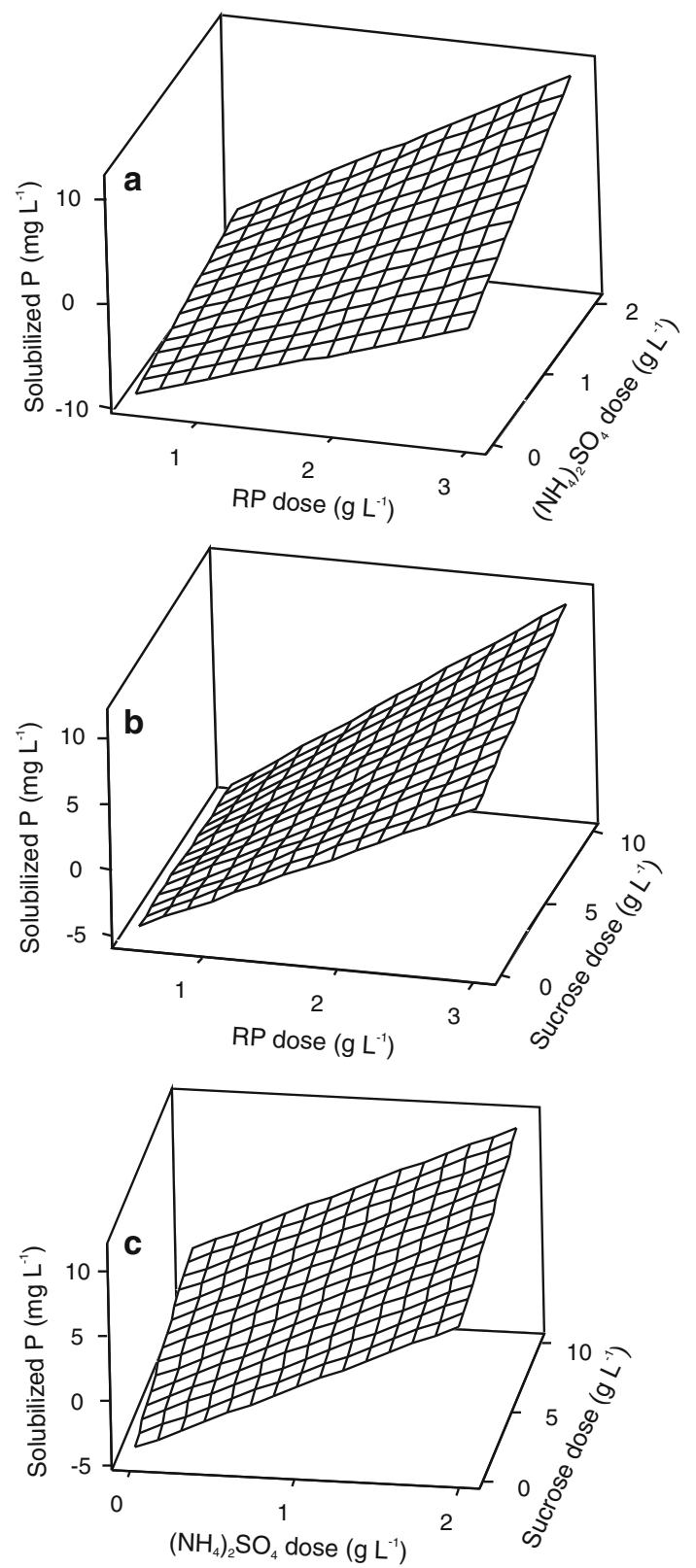

Fig. 3 Estimates of the level of solubilized $\mathrm{P}$ by the isolate $P$. islandicum FS30 as a function of the Catalão rock phosphate (RP), $\left(\mathrm{NH}_{4}\right)_{2} \mathrm{SO}_{4}$ and sucrose doses: for a fixed dose of sucrose at $10 \mathrm{~g} \mathrm{~L}^{-1}(\mathbf{a})$, for a fixed dose of $\mathrm{N}$ at $2 \mathrm{~g} \mathrm{~L}^{-1}(\mathbf{b})$ and for a fixed dose of RP at $3 \mathrm{~g} \mathrm{~L}^{-1}$ (c)
Responses to increasing doses of RP

To determine to what extent $\mathrm{P}$ solubilization continues to respond positively to increases in RP doses, the isolate A. niger FS1 was selected for another experiment. For both Araxá and Catalão RPs, increasing RP doses led to higher levels of solubilized P. However, the percentage of $\mathrm{P}$ in the RPs that was solubilized decreased as the RP doses increased (Fig. 4). In this medium, neither the titratable acidity nor the final $\mathrm{pH}$ varied with the RP doses added. For both RPs, the titratable acidity and $\mathrm{pH}$ were, on average, $30 \mathrm{mmol} \mathrm{H} \mathrm{L}^{-1}$ and 2.2, respectively.

\section{Discussion}

Effects of different sucrose, $\left(\mathrm{NH}_{4}\right)_{2} \mathrm{SO}_{4}$ and RP doses

Our results showed that RP dose was the most important factor affecting the level of solubilized $\mathrm{P}$ at the end of fungal growth under the tested treatments. Higher RP doses promoted higher solubilized P. Sucrose supplementation was only required for a single treatment. At the proportion
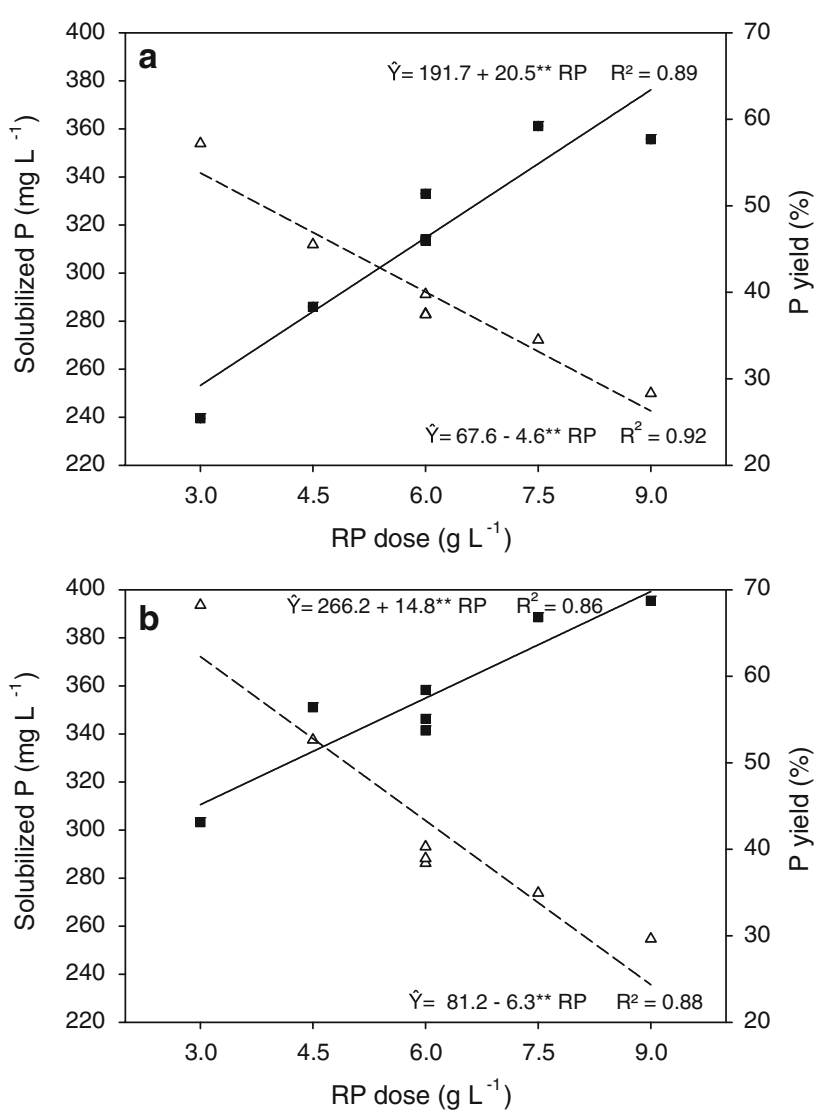

Fig. 4 Solubilized $\mathrm{P}$ (filled square) and yield of solubilized $\mathrm{P}$ (triangle) by the isolate A. niger FS1 as a function of the Araxá (a) or Catalão (b) rock phosphates. $* *$ Significant by the $t$ test $(p<0.01)$ 
of bagasse used, about $30 \mathrm{~g} \mathrm{~L}^{-1}$ of soluble sugars were added to the fermentation medium. These sugars derived from the bagasse must have been sufficient to supply the necessary $\mathrm{C}$ for fungal metabolism and RP solubilization, explaining the lack of significant effects of sucrose supplementation on RP solubilization. For instance, Vassilev et al. (1996) obtained up to $76 \%$ of RP solubilization using Czapek's solution containing $30 \mathrm{~g} \mathrm{~L}^{-1}$ of sucrose. This fact represents an advantage of using sugarcane bagasse as a substrate for SSF, considering that $\mathrm{C}$ addition to SSF systems can be costly.

$\left(\mathrm{NH}_{4}\right)_{2} \mathrm{SO}_{4}$ effects were variable among the treatments and the fungal isolates showed distinct requirements for $\mathrm{N}$ in the growth medium. For A. niger FS1, $\left(\mathrm{NH}_{4}\right)_{2} \mathrm{SO}_{4}$ decreased $\mathrm{P}$ solubilization and titratable acidity. Similar results were observed for Penicillium purpurogenum, which produced less organic acids and solubilized less $\mathrm{P}$ when higher $\left(\mathrm{NH}_{4}\right)_{2} \mathrm{SO}_{4}$ doses were added to the liquid culture (Scervino et al. 2011). Nahas et al. (1990) observed that higher growth is followed by lower RP solubilization, $\mathrm{pH}$ reduction, and acid production when $\mathrm{NH}_{4} \mathrm{NO}_{3}$ is added to culture medium. This is attributed to the fact that nitrogen stimulates the synthesis of cellular materials by the fungus (Hang et al. 1977), and the fungal cells will, therefore, devote less carbon to the production of acids. The bagasse used in this work could supply about $0.34 \mathrm{~g} \mathrm{~L}^{-1}$ of $\mathrm{N}$ to the fermentation medium. This value is three times larger than that found to be optimal for citric acid production by A. niger (Ikram Ul et al. 2005). Thus, we speculate that the negative correlation observed between $\left(\mathrm{NH}_{4}\right)_{2} \mathrm{SO}_{4}$ dose and titratable acidity results from the inhibition of organic acids production when more $\mathrm{N}$ is added to the fermentation medium. As a consequence, RP solubilization decrease because organic acids are important factors involved in the solubilization process. Thus, our results indicate that the available $\mathrm{N}$ in the sugarcane bagasse may be sufficient to maintain fungal metabolism within a range that favors RP solubilization.

When $P$. canescens $\mathrm{FS} 23$ was inoculated in the media with Araxá $\mathrm{RP}$ at the lower doses, $\left(\mathrm{NH}_{4}\right)_{2} \mathrm{SO}_{4}$ supplementation led to decreased $\mathrm{P}$ solubilization. Higher fungal growth due to increased $\mathrm{N}$ availability is known to stimulate $\mathrm{P}$ consumption from the growth medium (Nahas et al. 1990). Thus, when lower RP doses were added to the SSF system, the lower quantities of $\mathrm{P}$ solubilized by the fungus must have been exhausted rapidly. On the other hand, at higher RP doses, $\left(\mathrm{NH}_{4}\right)_{2} \mathrm{SO}_{4}$ favored solubilization. A large Ca-sink is necessary to remove $\mathrm{Ca}$ from the medium and to allow the continuity of RP solubilization (Robinson and Syers 1990). In our treatments, when there was a higher amount of Araxá RP to be solubilized, increasing N availability could have stimulated fungal growth and the growing mycelial mass may have become a major sink for
Ca generated from RP solubilization, leading to higher soluble P yields.

Among the fungal isolates tested, A. niger FS1 stood out for being the most efficient at solubilizing both Catalão and Araxá RPs. This fungus promoted solubilization percentages of 57 and $58 \%$ of the total P present in Araxá and Catalão RPs, respectively. These values are higher than those obtained by Vassileva et al. (1998) who obtained a $43 \%$-solubilization of an RP from Morocco (12.8\% P) using A. niger in an SSF system with olive cake as substrate. Aspergillus niger is widely known because of its capacity to produce organic acids at high amounts, such as citrate, oxalate, and gluconate (Magnuson and Lasure 2004). This characteristic highlights A. niger as a potential P solubilizer, taking into account that organic acids are molecules with high capability to release $\mathrm{P}$ from insoluble forms (Fox et al. 1990). Moreover, A. niger FS1 demonstrated higher solubilization ability with very simple nutritional requirements. The response surfaces clearly show that, except for A. niger FS1, all the fungal isolates need a combination of high RP and $\left(\mathrm{NH}_{4}\right)_{2} \mathrm{SO}_{4}$ doses to obtain maximal solubilization (Figs. 1, 2, 3). On other hand, for A. niger FS1, the highest amounts of solubilized $\mathrm{P}$, for both Araxá and Catalão RPs, could be achieved with no $\left(\mathrm{NH}_{4}\right)_{2} \mathrm{SO}_{4}$ or sucrose addition (Table 1). This is extremely interesting and demonstrates that A. niger FS1 is capable of solubilizing part of the $\mathrm{P}$ present in the RPs using only the $\mathrm{C}$ and $\mathrm{N}$ sources present in the sugarcane bagasse.

\section{Responses to increasing doses of RP}

A negative correlation between the amount of $\mathrm{P}$ solubilized and $\mathrm{P}$ yield was observed with increasing RP doses. This trend of reduction of $\mathrm{P}$ yield with increasing RP doses can be also calculated from the data of Xiao et al. (2008). The same phenomenon occurs when RP is added to soil and is often a consequence of insufficient acidity for RP solubilization, limited P-sink, and, especially, limited Ca-sink (Robinson et al. 1992; Robinson and Syers 1990). These explanations are also probably valid for the conditions observed in the SSF system. As the acidity remains unchanged among treatments, a fixed amount of RP can be solubilized by this mechanism. Because of this, when the doses of RP is increased, a smaller percentage of the P in the RP will be solubilized. Sinks for $\mathrm{Ca}$ and $\mathrm{P}$ under SSF correspond mostly to the fungal biomass. No apparent variation in fungal growth could be observed among the treatments tested in our study. Fungal growth was confined to the surface of the SSF medium, forming a thin layer that covered the entire substrate in all the treatments. Thus, when larger $\mathrm{RP}$ doses were added, $\mathrm{Ca}$ and $\mathrm{P}$ sinks, represented by mycelium, may have been quickly saturated, inhibiting the solubilization of a large portion of the added RP. 
This inverse relationship between solubilized $\mathrm{P}$ and $\mathrm{P}$ yield with increasing RP doses opens new avenues for optimizing RP solubilization. Strategies such as removing $\mathrm{Ca}$ from the fermentation medium, increasing the area available for fungal growth, and increasing initial inoculum could allow the solubilization of larger quantities of $\mathrm{P}$ even at high concentrations of RPs.

\section{Conclusions}

Based on our data we can affirm that A. niger FS1 is the most efficient fungal isolate for SSF-based RP solubilization system proposed, achieving high $\mathrm{P}$ yields with lower nutritional requirements. Sugarcane bagasse can supply the $\mathrm{C}$ and $\mathrm{N}$ required for fungal RP solubilization. The system proposed could be efficiently used to obtain a low cost biofertilizer rich in $\mathrm{P}$ combining $\mathrm{RP}$, sugarcane bagasse, and $A$. niger. Further work is necessary to optimize $\mathrm{P}$ yields at high RP doses, searching an optimal equilibrium between soluble $\mathrm{P}$ in the product and a good $\mathrm{P}$ recovery from the RP.

Acknowledgments The authors would like to thank $\mathrm{CNPq}$ for granting a scholarship to the first author, and Capes/PROEX for financing this research.

\section{References}

Ahuja A, Ghosh SB, D'Souza SF (2007) Isolation of a starch utilizing, phosphate solubilizing fungus on buffered medium and its characterization. Bioresour Technol 98(17):3408-3411. doi: 10.1016/j.biortech.2006.10.041

Banik S, Dey B (1982) Available phosphate content of an alluvial soil as influenced by inoculation of some isolated phosphatesolubilizing micro-organisms. Plant Soil 69(3):353-364. doi: $10.1007 / \mathrm{bf02372456}$

Braga JM, Defelipo BV (1974) Determinação espectrofotométrica de fósforo em extratos de solo e material vegetal. Rev Ceres 21: $73-85$

Chuang CC, Kuo YL, Chao CC, Chao WL (2007) Solubilization of inorganic phosphates and plant growth promotion by Aspergillus niger. Biol Fertil Soils 43(5):575-584. doi:10.1007/s00374006-0140-3

Fox TR, Comerford NB, McFee WW (1990) Phosphorus and aluminum release from a spodic horizon mediated by organic acids. Soil Sci Soc Am J 54(6):1763-1767. doi:10.2136/sssaj $1990.03615995005400060043 x$

Hang YD, Splittstoesser DF, Woodams EE, Sherman RM (1977) Citric acid fermentation of brewery waste. J Food Sci 42(2): 383-384. doi:10.1111/j.1365-2621.1977.tb01504.x

Ikram Ul H, Ali S, Qadeer MA, Iqbal J (2005) Optimization of nitrogen for enhanced citric acid productivity by a 2-deoxy Dglucose resistant culture of Aspergillus niger NGd-280. Bioresour Technol 96(5):645-648. doi:10.1016/j.biortech.2004.06.010

Kumar D, Jain VK, Shanker G, Srivastava A (2003) Citric acid production by solid state fermentation using sugarcane bagasse.
Process Biochem 38(12):1731-1738. doi:10.1016/s0032-9592(02) 00252-2

Magnuson JK, Lasure LL (2004) Organic acid production by filamentous Fungi. In: Tkacz JS, Lange L (eds) Advances in fungal biotechnology for industry, agriculture, and medicine. Kluwer Academic/Plenum Publishers, New York, pp 307-340

Nahas E, Banzatto DA, Assis LC (1990) Fluorapatite solubilization by Aspergillus niger in vinasse medium. Soil Biol Biochem 22(8):1097-1101. doi:10.1016/0038-0717(90)90035-X

Novais RF, Smith TJ (1999) Fósforo em solo e planta em condições tropicais, 1st edn. UFV, Viçosa

Reyes I, Bernier L, Simard RR, Tanguay P, Antoun H (1999) Characteristics of phosphate solubilization by an isolate of a tropical Penicillium rugulosum and two UV-induced mutants. FEMS Microbiol Ecol 28(3):291-295. doi:10.1016/S0168-6496 (98)00118-4

Reyes I, Baziramakenga R, Bernier L, Antoun H (2001) Solubilization of phosphate rocks and minerals by a wild-type strain and two UV-induced mutants of Penicillium rugulosum. Soil Biol Biochem 33(12-13):1741-1747. doi:10.1016/S0038-0717(01) 00099-2

Robinson JS, Syers JK (1990) A critical evaluation of the factors influencing the dissolution of Gafsa phosphate rock. J Soil Sci 41(4):597-605. doi:10.1111/j.1365-2389.1990.tb00229.x

Robinson JS, Syers JK, Bolan NS (1992) Importance of proton supply and calcium-sink size in the dissolution of phosphate rock materials of different reactivity in soil. J Soil Sci 43(3):447-459. doi:10.1111/j.1365-2389.1992.tb00151.x

Scervino JM, Papinutti VL, Godoy MS, Rodriguez MA, Della Monica I, Recchi M, Pettinari MJ, Godeas AM (2011) Medium pH, carbon and nitrogen concentrations modulate the phosphate solubilization efficiency of Penicillium purpurogenum through organic acid production. J Appl Microbiol 110(5):1215-1223. doi:10.1111/j.1365-2672.2011.04972.x

Soccol CR, Vandenberghe LPS (2003) Overview of applied solidstate fermentation in Brazil. Biochem Eng J 13(2-3):205-218. doi:10.1016/s1369-703x(02)00133-x

Vassilev N, Vassileva M (2003) Biotechnological solubilization of rock phosphate on media containing agro-industrial wastes. Appl Microbiol Biotechnol 61(5-6):435-440. doi:10.1007/s00253003-1318-3

Vassilev N, Franco I, Vassileva M, Azcon R (1996) Improved plant growth with rock phosphate solubilized by Aspergillus niger grown on sugar-beet waste. Bioresour Technol 55(3):237-241. doi:10.1016/0960-8524(96)00008-9

Vassilev N, Vassileva M, Fenice M, Federici F (2001) Immobilized cell technology applied in solubilization of insoluble inorganic (rock) phosphates and $\mathrm{P}$ plant acquisition. Bioresour Technol 79(3):263-271. doi:10.1016/S0960-8524(01)00017-7

Vassilev N, Medina A, Azcon R, Vassileva M (2006) Microbial solubilization of rock phosphate on media containing agroindustrial wastes and effect of the resulting products on plant growth and P uptake. Plant Soil 287(1-2):77-84. doi:10.1007/ s11104-006-9054-y

Vassileva M, Vassilev N, Azcon R (1998) Rock phosphate solubilization by Aspergillus niger on olive cake-based medium and its further application in a soil-plant system. World J Microbiol Biotechnol 14(2):281-284. doi:10.1023/A:1008858802855

Xiao CQ, Chi RA, Huang XH, Zhang WX, Qiu GZ, Wang DZ (2008) Optimization for rock phosphate solubilization by phosphatesolubilizing fungi isolated from phosphate mines. Ecol Eng 33(2):187-193. doi:10.1016/j.ecoleng.2008.04.001 